(C) С.С. Філіп, Ю.П. Скрипинець, 2019

УДК 616.381-002-085:612.017

\title{
Динаміка показників ендогенної інтоксикації та неспецифічної резистентності при комплексному лікуванні перитоніту із застосуванням ендолімфатичної комбінованої терапії
}

\author{
С.С. Філіп, Ю.П. Скрипинець
}

Ужггородський наиіональний університет, медичний факультет, кафедра загальної хірургії,

Ужгород

\section{Реферат}

Вступ. Шляхи введення фармакологічних препаратів при гнійно-септичних захворюваннях різноманітні, але найбільш ефективним на даний час визнано ендолімфатичний, який дає можливість впливати на збудника та його токсини безпосередньо в лімфатичній системі до того, як вони потраплять у загальний кровообіг $[1,2,5]$. Ендолімфатичний метод введення лікарських чинників дозволяе створити та тривалий час підтримувати в лімфатичній системі терапевтичні концентрації антибіотиків, що дає можливість використовувати даний метод у комплексному лікуванні перитонітів [3,4,5,6,].

Мета дослідження: покращити результати комплексного лікування хворих на гострий перитоніт на основі включення в комплекс лікування ендолімфатичної комбінованої терапії.

Матеріали та методи. Обстежено 37 пацієнтів з гострим перитонітом (ГП), віком $19-72$ роки, які лікувалися в хірургічному відділенні КЗ Ужгородської районної лікарні станції Ужгород упродовж 2015-2019 рр. Пацієнти розділені на групи - основну та контрольну. До контрольної групи ввійшло 15 хворих на ГП, яким проводилось комплексне лікування перитоніту без застосування ендолімфатичної комбінованої терапії (КЛП). В основну групу ввійшло 22 пацієнти з ГП, яким у комплексному лікуванні ГП застосовували ендолімфатичну комбіновану терапію (ЕКТ) [3]. Для оцінки рівня ендогенної інтоксикації проводили визначення рівня пептидів середньої молекулярної маси (ПСММ) сироватки крові та розрахунок лейкоцитарного індексу інтоксикації (ЛІІ). 3 метою оцінки активності неспецифічного захисту організму визначали індекс резистентності організму (IPO).

Результати досліджень та їх обговорення. Аналіз отриманих даних вказує, що застосування ендолімфатичної комбінованої терапії в комплексному лікуванні хворих на перитоніт призводить до швидшої ліквідації явищ ендогенної інтоксикації, а саме: зменшується загальна кількість лейкоцитів на $25 \%$, кількість паличкоядерних найтрофілів - на $35 \%$, лейкоцитарний індекс інтоксикації (ЛІІ) - на $25 \%$, рівень пептидів середньої молекулярної маси (ПСММ) - на 20\%, зростає індекс резистентності організму на 25\%, що сприяє більш швидшому відновленню захисних функцій організму у порівнянні із контрольною групою хворих.

Висновки. Застосування ендолімфатичної комбінованої терапії в комплексному лікуванні хворих на перитоніт сприяє більш швидшій ліквідації явищ ендогенної інтоксикації та сприяє швидшому одужанню хворих.

Ключові слова: перитоніт, ендолімфатична комбінована терапія, ендогенна інтоксикація, неспецифічна резистентність.

Dynamics of endogenic intoxication findings and non - specific resistance in complex treatment of peritonitis by using endolymphatic combine therapy

S.S. Filip, Y.P. Skripinets

Uzhhorod National University, department of medicine, chair of general surgery, Uzhhorod

\section{Abstract}

Introduction. The ways of usage of pharmacological drugs during the festering setptic diseases are different. Today the most effective is endolymphatic, which influencies causative agent and toxins directly in the lymphatic system before they enter the blood circle. Endolymphatic method of drug usage allows to create and support therapeutic concentrated doses of antibiotics in the lymphatic system. Thus this method can be used in a complex treatment of peritonitis.

Aim of research. Our aim is to improve the results of a complex treatment with endolymphatic combined therapy (ECT) for patients with acute peritonitis.

Materials and methods. 37 patients, aged 19-72 with acute peritonitis have been examined. These patients were treated at the surgical department of Uzhhorod regional hospital in the period of 2015-2019. There were two groups of patients: main group with 22 patients and control group with 15 patients. Only main group of patients used endolymfatic combined therapy (ECT). To asses the level of endogenic intoxication we determined the level of middle molecular mass blood serum and made calculation of leucocyte index of intoxication. To assess the activity of non-specific defense of the body we determined body resistance index.

Results and discussion. The analyses of the received data show that the usage of endolymfatic combined therapy (ECT) within the complex treatment of peritonitis leads to fast elimination of endogenous intoxications phenomena. Namely, leucocytes are $25 \%$ less, rod-core neutrophils are $35 \%$ less, leucocyte intoxication index is $25 \%$ less, level of peptides with middle molecular mass is $20 \%$ less, index of a body resistance is $25 \%$ higher, are this leads to a quick recovery of the body defence forces in comparison to a control group patients.

Conclusion. Clinicaly enabled us to establish that in case of the complex treatment of peritonitis the endolymphatic combine therapy diminishes endogenic intoxication contributes rapid normalisation of the immunologic findings and rapid restored protective function of organism.

Key words: peritonitis, endolymphatic combined therapy (ECT), endogenic intoxication, non-specific resistance. 
Вступ. Шляхи введення фармакологічних препаратів при гнійно-септичних захворюваннях різноманітні, але найбільш ефективним на даний час визнано ендолімфатичний, який дає можливість впливати на збудника та його токсини безпосередньо в лімфатичній системі до того, як вони потраплять у загальний кровообіг [1,2,5]. Ендолімфатичний метод введення лікарських чинників дозволяє створити та тривалий час підтримувати в лімфатичній системі терапевтичні концентрації антибіотиків, що дає можливість використовувати даний метод в комплексному лікуванні перитонітів $[3,4,5,6$,$] . Застосування ендолімфатичної комбіно-$ ваної терапії в комплексному лікуванні перитонітів дає можливість безпосередньо впливати на збудника та його токсини в лімфатичному руслі, оскільки транспорт мікробних токсинів та метаболітів із гнійно-септичного вогнища здійснюється в регіонарні та колекторні лімфовузли, які є біологічним фільтром і здатні механічно затримувати мікро- та макроагрегати лімфи, бактерії, відламки форменних елементів, великі корпускулярні токсичні сполуки, виробляти біологічно активні речовини $[1,2,3]$.

Мета дослідження: покращити результати комплексного лікування хворих на гострий перитоніт на основі включення в комплекс лікування ендолімфатичної комбінованої терапії.

Матеріали та методи. Обстежено 37 пацієнтів із гострим перитонітом (ГП) віком 19-72 роки, які лікувалися в хірургічному відділенні КЗ Ужгородської районної лікарні станції Ужгород упродовж 2015-2019 рр. Пацієнти розділені на групи - основну та контрольну. До контрольної групи ввійшло 15 хворих на ГП, яким проводилось комплексне лікування перитоніту без застосування ендолімфатичної комбінованої терапії (КЛП). В основну групу ввійшло 22 пацієнти з ГП, яким у комплексному лікуванні ГП застосовували ендолімфатичну комбіновану терапію (ЕКТ) [3]. Для оцінки рівня ендогенної інтоксикації проводили визначення рівня пептидів середньої молекулярної маси (ПСММ) сироватки крові та розрахунок лейкоцитарного індексу інтоксикації (ЛІІ). 3 метою оцінки активності неспецифічного захисту організму визначали індекс резистентності організму (IPO).

Результати досліджень та їх обговорення. Через 24 години після проведення оперативного втручання та ліквідації причини гострого перитоніту у пацієнтів основної клінічної групи (ЕКТ) загальна кількість лейкоцитів становила $12,5 \pm 0,65 * 10^{9} / л$ та у контрольній клінічній групі (КЛП) - 12,9 $\pm 0,68 * 10^{9} / л$, що вище рівня групи здорових людей в 1,8 разу. В процесі лікування у пацієнтів обох груп виявлено позитивну динаміку рівня загального лейкоцитозу в напрямку до його зменшення, що краще відбувалося у групі хворих, яким у комплексному лікуванні перитоніту застосовували ендолімфатичну комбіновану терапію. На п’яту добу від початку лікування загальна кіль- кість лейкоцитів у крові пацієнтів основної клінічної групи (ЕКТ) була в 1,2 разу нижчою за кількість лейкоцитів у пацієнтів контрольної групи (КЛП) та продовжувала зменшуватися і на сьому добу становила в основній групі $6,5 \pm 0,3 * 10^{9} /$ л та $7,8 \pm 0,4 * 10^{9} /$ л - у контрольній $\left(\mathrm{P}_{1}<0,05\right)$, що на $20 \%$ залишалась вище рівня основної групи. На дев'яту добу загальна кількість лейкоцитів у крові пацієнтів основної клінічної групи (ЕКТ) зменшилась до $5,9 \pm 0,2 * 10^{9} /$ л, а в контрольній практично не змінилась, що вказує на більш швидше зменшення лейкоцитозу у пацієнтів основної клінічної групи у порівнянні із контрольною, де ендолімфатична комбінована терапія в комплексному лікуванні перитоніту не застосовувалась. Оцінюючи динаміку змін лейкоцитів крові у пацієнтів обох груп, відзначено, що відновні процеси краще проходять у тих пацієнтів, яким у комплексному лікуванні перитоніту застосовували ендолімфатичну комбіновану терапію.

Рівень еозинофілів у пацієнтів обох груп упродовж усього періоду лікування залишався відносно сталим

Явища інтоксикації, зумовлені перитонітом, спричинили появу незрілих форм нейтрофілів мієлоцитів у пацієнтів контрольної клінічної групи (КЛП), які утримувалися впродовж усього періоду лікування перитоніту у пацієнтів цієї групи і не приходили до норми навіть на сьому добу. Їх кількість на першу добу після операції становила $0,09 \pm 0,06 \%$ та в подальшому зменшилася у 3 рази на третю добу від початку лікування і в кількості $0,025 \pm 0,02 \%$ виявлялась на сьому добу від початку лікування за рахунок хворих із розлитим перитонітом.

Кількість юних нейтрофілів через 24 години від початку лікування (перша доба після операції) у контрольній групі становила $1,5 \pm 0,2 \%$ та у основній $-1,6 \pm 0,2 \%$. У процесі подальшого лікування відмічено зменшення кількості юних нейтрофілів в основній групі у порівнянні із контрольною. На третю добу від початку лікування кількість їх у основній групі була в 3,3 разу нижчою, ніж у контрольній. На п’яту добу від початку лікування у контрольній клінічній групі (КЛП) кількість юних нейтрофілів була $0,17 \pm 0,05 \%$, а на сьому 0,08 $\pm 0,05 \%$, на відміну від основної (РЕКТ), де вже на п'яту добу від початку лікування юних нейтрофілів у загальному аналізі крові не було. Кількість паличкоядерних нейтрофілів на першу добу після оперативного лікування становила в обох групах у 9 разів вище рівня групи здорових людей.

У процесі лікування кількість паличкоядерних нейтрофілів зменшувалася в обох групах пацієнтів упродовж усього періоду клінічного спостереження за хворими. На третю добу від початку лікування кількість паличкоядерних нейтрофілів була на 12\% вище рівня основної групи (ЕКТ). На п’яту добу кількість паличкоядерних нейтрофілів у ос- 
новній групі зменшилась до 7,3 $\pm 1,2 \%$, що у 1,2 разу нижче рівня контрольної групи пацієнтів $\left(\mathrm{P}_{1}<0,05\right)$. Через дев'ять діб від початку лікування у основній групі (ЕКТ) кількість паличкоядерних

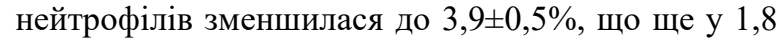
разу вище рівня групи здорових людей $(\mathrm{P}<0,01)$, але в 1,6 разу нижча аналогічного показника у пацієнтів контрольної клінічної (КЛП) групи $\left(\mathrm{P}_{1}<0,05\right)$.

Перебіг перитоніту супроводжується явищами імунодепресії. Загальна кількість лімфоцитів периферичної крові у пацієнтів обох груп на першу добу після оперативного лікування була на $62 \%$ нижче рівня групи здорових людей. У процесі лікування у міру ліквідації явищ інтоксикації в обох групах хворих виявлено зростання загальної кількості лімфоцитів.

На п’яту добу лікування загальна кількість лімфоцитів у контрольній групі була $25,0 \pm 0,9 \%$, від третьої до п’ятої доби зросла на $20 \%$, тоді як у основній клінічній групі, де в комплексному лікуванні перитоніту застосовували ендолімфатичну комбіновану терапію, аналогічний показник становив $29,6 \pm 1,2 \%$, що на $22 \%$ вище рівня контрольної групи (КЛП).

Від третьої до п’ятої доби в основній групі загальна кількість лімфоцитів зросла на 23\%, але значний ефект лімфостимуляції відзначено у пацієнтів основної клінічної групи на сьому добу лікування, де загальна кількість лімфоцитів зросла до $37,5 \pm 0,8 \%$, що на $22 \%$ вище рівня контрольної групи $\left(\mathrm{P}_{1}<0,05\right)$. На дев'яту добу загальна кількість лімфоцитів в основній групі на 20\% перевищувала аналогічну в контролі.

Перебіг перитоніту супроводжується явищами ендогенної інтоксикації, які зумовлені мікробною флорою та іiі токсинами, що всмоктуються із очеревинної порожнини та циркулюють у кров'яному руслі. Через 24 години від початку лікувальних заходів лейкоцитарний індекс інтоксикації у обох клінічних групах пацієнтів був високим, у контрольній групі становив $4,8 \pm 0,4$ та в основній $-5, \pm 0,7$, що в 7,5 разу вище рівня норми у контролі, та в 9 разів вище рівня групи здорових осіб в основній клінічній групі.

У процесі лікування прояви інтоксикації зменшувалися. Краща динаміка процесу зменшення інтоксикації спостерігається у пацієнтів основної клінічної групи, яким в комплексному лікуванні перитоніту застосовували ендолімфатичну комбіновану терапію.

На третю добу від початку лікування ЛІІ у контрольній клінічній групі зменшився до 2,8 $\pm 0,3$, тобто на $43 \%$ у порівнянні із першою добою від початку лікування, в основній групі (РЕКТ) - на $74 \%$ у порівнянні із першою добою від початку лікування і становив 1,6 $\pm 0,19$, що на $46 \%$ нижче рівня ЛІІ у контрольній групі (КЛП) $\left(\mathrm{P}_{1}<0,01\right)$.

У період від третьої до п'ятої доби прояви інтоксикації продовжували зменшуватися у пацієн- тів обох клінічних груп, але швидша ліквідація явищ інтоксикації простежувалася у пацієнтів основної клінічної групи, яким у комплексному лікуванні перитоніту застосовували ендолімфатичну комбіновану терапію.

На п’яту добу від початку лікування лейкоцитарний індекс інтоксикації в основній клінічній групі зменшився на $44 \%$ у порівнянні із третьою добою від початку лікування, у контрольній групі (КЛП) ЛІІ зменшився на $31 \%$ у порівнянні із третьою добою від початку лікування, та становив $1,8 \pm 0,34$, що на $54 \%$ вище за показник ЛІІ в основній клінічній групі (РЕКТ) $\left(\mathrm{P}_{1}<0,01\right)$.

На сьому добу від початку лікування стан хворих в обох клінічних групах значно покращився, про що свідчать показники ЛІІ. У контрольній клінічній групі ЛІІ зменшився до $1,1 \pm 0,05$, що вище рівня норми на $42 \%(\mathrm{P}<0,01)$, та в основній - до $0,73 \pm 0,05$, що наближається до рівня норми, але ще вище нього на $13 \%(\mathrm{P}<0,01)$ та на $33 \%$ нижче рівня контролю $\left(\mathrm{P}_{1}<0,01\right)$.

На дев'яту добу після операції ЛІІ в основній клінічній групі був на 25\% нижче рівня контрольної клінічної групи.

Збільшення рівня молекул середньої маси у пацієнтів обох клінічних груп $є$ проявом зростання ендогенної інтоксикації. У контрольній та основній групах рівень ПСММ був вище рівня групи здорових осіб на 72\%. Відповідно і коефіцієнт Кс у обох клінічних групах був на $33 \%$ нижче рівня групи здорових осіб, що свідчить про розвиток в організмі септичного процесу.

Рівень пептидів середньої молекулярної маси на третю добу від початку лікування зменшувався в обох групах, але в основній був на 23\% нижче рівня контролю. Аналогічно зростає коефіцієнт Кс

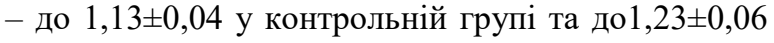
- в основній (ЕКТ), що на 9\% вище рівня контрольної клінічної групи (КЛП) $\left(\mathrm{P}_{1}<0,05\right)$ та на $8 \%$ нижче рівня групи здорових людей $(\mathrm{P}<0,05)$.

Рівень ПСММ також знижувався паралельно із усуненням інтоксикації і на п'яту добу в основній клінічній групі був на $21 \%$ вище рівня норми та у контрольній - на $31 \%$ вище рівня основної групи $\left(\mathrm{P}_{1}<0,01\right)$, та на $45 \%$ вище рівня групи здорових

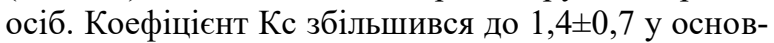
ній клінічній групі (ЕКТ) $\left(\mathrm{P}_{1}<0,01\right)$ та до $1,25 \pm 0,5$ в контрольній групі (КЛП), що наближається до рівня групи здорових людей, але нижче нього на 5\% $(\mathrm{P}<0,01)$.

На дев'яту добу рівень ПСММ в основній клінічній групі (ЕКТ) на 20\% був нижчим за рівень

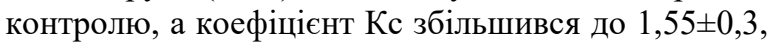
що на 10\% вище рівня контрольної клінічної групи.

Оцінюючи стан неспецифічного захисту організму, встановлено, що індекс резистентності організму на першу добу після операції у пацієнтів обох клінічних груп був низьким у порівнянні зі здоровими за рахунок лейкоцитозу та високого 
лекоцитарного індексу інтоксикації та був однаковим в обох групах. У процесі лікування спостерігалась позитивна динаміка до нормалізації індексу резистентності організму. На третю добу після операції індекс резистентності організму в контрольній групі зріс незначно у порівнянні із першою добою та становив $0,13 \pm 0,01$, тоді як в основній групі він зріс до $0,24 \pm 0,02$. Від третьої до п’ятої доби індекс резистентності організму в обох групах зріс і в основній групі був у 1,9 разу вище рівня контролю.

У процесі лікування зменшувались явища інтоксикації, стан хворих покращувався, що зумовило зростання індексу резистентності організму на дев'яту добу після операції в основній клінічній групі вище контролю на 25\%, однак цей показник був нижче рівня групи здорових людей на 20\% в основній та на $35 \%$ в контрольній клінічних групах.

Висновки. Застосування ендолімфатичної комбінованої терапії в комплексному лікуванні хворих на перитоніт сприяє більш швидшій ліквідації явищ ендогенної інтоксикації, а саме: зменшується загальна кількість лейкоцитів на $25 \%$, кількість паличкоядерних найтрофілів на $35 \%$, лейкоцитарний індекс інтоксикації (ЛІІ) - на 25\%, рівень пептидів середньої молекулярної маси (ПСММ) - на 20\%, зростає індекс резистентності організму на 25\%, що сприяє більш швидшому відновленню захисних функцій організму у порівнянні із контрольною групою хворих.

Інформація про конфлікт інтересів: конфлікт інтересів при виконанні наукового дослідження та підготовці даної статті відсутній.

Інформація про фінансування: автори гарантують, що вони не отримували жодних винагород у будь-якій формі, здатних вплинути на результати роботи.

Особистий внесок кожного автора у виконання роботи:

Філіп С.С. - розробка концепції і дизайну дослідження, аналіз отриманих даних, редагування.

Скрипинець Ю.П. - збір матеріалу, статистична обробка даних, підготовка та написання частини тексту.

\section{Список використаної літератури}

1. Alekseev AA, Buianov VM, Radzykhovskyi AP, Shymanko YY. Lymfohennaia detoksykatsyia. K. Naukova dumka. 1988:228 s. [In Russian].

2. Hryl VK, Mymynoshvyly OY, Korchahyn EP, Mymynoshvyly AO Priamaia antehradnaia эndolymfatycheskaia terapiia $\mathrm{v}$ lechenyy posleoperatsyonnoho pareza kyshechnyka pry rasprostranennom peretonyte. Ukrainskyi Zhurnal Khirurhii. 2011;5(14):91-94. [In Russian].

3. Kolosovych IV, Chemodanov PV, Zapolska KM, Bondarchuk OL. Osoblyvosti perebihu bakterialnoho perytonitu pry uskladnenykh perforatsiieiu vyrazkakh dvanadtsiatypaloi kyshky // Ukrainskyi Zhurnal Khirurhii 2011;1(10):23-28. [In Ukrainian].

4. Muntian SO, Barannik SI, Chaban OP, Shadrin IS. Rol imunomoduliuiuchoi terapii v rannomu pisli?operatsiinomu periodi u khvorykh $\mathrm{z}$ proryvnoiu piloroduodenalnoiu vyrazkoiu, perytonitom. Klinichna khirurhiia. 2005;11-12:89-90. [In Ukrainian].

5. Symodeiko AA, Filip SS, Panto VI, Skrypynets YuP, Filip MS, vynakhidnyky; Symodeiko AA, Filip SS, patentovlasnyky. Sposib endolimfonoduliarnoi terapii pry hniino-zapalnykh zakhvoriuvanniakh. Patent Ukrainy №52202 A. 2002 Hrud 16.

6. Polianskyi IIu, Hrynchuk FV, Andriiets VV, Moskaliuk VI, Moroz VA. Alhorytm likuvalnoi taktyky pry hostromu perytoniti. Suchasni medychni tekhnolohii. 2011;3-4:310-12. [In Ukrainian].

Стаття надійшла до редакції: 22.01.2019 р. 